\section{Investigation into Cryptosporidium and Giardia in bivalve mollusks farmed in Sardinia region and destined for human consumption}

\author{
Tiziana Tedde, ${ }^{1}$ Gabriella Piras, ${ }^{1}$ \\ Sara Salza, ${ }^{1}$ Rosa Maria Nives, ${ }^{1}$ \\ Giovanna Sanna, ${ }^{1}$ Sebastiana Tola, ${ }^{1}$ \\ Jacopo Culurgioni, ${ }^{2}$ Cristina Piras, ${ }^{2}$ \\ Paolo Merella, ${ }^{2}$ Giovanni Garippa, ${ }^{2}$ \\ Sebastiano Virgilio'
}

1'Istituto Zooprofilattico Sperimentale della Sardegna, Sassari; '2Dipartimento di

Biologia Animale, Sezione di

Parassitologia e Malattie parassitarie, Università di Sassari, Italy

\section{Abstract}

Cryptosporidium and Giardia are protozoan parasites transmitted by fecal-oral ingestion of (00)cysts, and are responsible for enteritis in several animal species and humans worldwide. These (00)cysts can survive for over a year in aquatic environments and can accumulate in bivalve mollusks, which filter large volumes of water. The aim of this study is to evaluate the natural occurrence of Cryptosporidium and Giardia contamination in different specimens of edible bivalves mollusks from farming sites of the western and north-eastern coasts of Sardinia. From April 2011 to February 2012, 1095 specimens of Mytilus galloprovincialis and 240 of Crassostrea gigas were sampled from Olbia and Oristano gulf and San Teodoro pond. Hepatopancreas and gills, including the labial palp, were examined for oocysts and cysts after pooling and homogenisation using different techniques: i) staining for light and fluorescence microscopy; ii) direct immunofluorescence (IF) Merifluor ${ }^{\circledR}$ test Cryptosporidium Giardia (Meridian Bioscience Inc., Cincinnati, $\mathrm{OH}$, USA); and iii) molecular procedures. However, in the context under study, all mollusks examined with the three main diagnostic techniques were negative for both parasites pointing out the hypothetically low zoonotic risk related to Cryptosporidium and Giardia in bivalves, especially Mytilus galloprovincialis and Crassostrea gigas.

\section{Introduction}

The flagellate Giardia and the coccidian Cryptosporidium are protozoan parasites of vertebrates and well-known causative agents of gastrointestinal diseases. Giardia cysts and Cryptosporidium oocysts excreted by infected hosts may cause human infection (especially in young and/or immunodeficient subjects) through ingestion of contaminated water and/or food (Rodriguez-Hernandez et al., 1994; Graczyk et al., 1997; Lowery et al., 2001; Glaberman et al., 2002). Freshwater contaminated by human and animal waste may be a source of infection in marine environments, as well as of several organisms in estuaries and coastal areas. As protozoan cysts and oocysts are able to survive for a long time in these environments, they can be accumulated in the tissues or organs of some aquatic filtering organisms, such as bivalve mollusks. The presence of Giardia and Cryptosporidium in bivalve mollusks has been reported in many marine areas in the proximity of contaminated wastewater (Graczyk et al., 1999; Freire-Santos et al., 2000; Gomez-Couso et al., 2004, 2005; Guiguet Leal et al., 2008; Mladineo et al., 2009). There has been increasing awareness on the presence of these parasites in edible bivalves in Italy, which has led to recent studies along the coastline of the Adriatic sea (Giangaspero et al., 2004; Molini et al., 2004; Traversa et al., 2004; Berrilli et al., 2008). As concerns Sardinia, there are currently no relevant data on the presence of these parasites in bivalves.

The aim of the present paper is to evaluate the level of Giardia and Cryptosporidium contamination of Mytilus galloprovincialis and Crassostrea gigas collected from Sardinia coast and to assess the validity of different diagnostic techniques for the detection and identification at species level of these protozoan parasites.

\section{Materials and Methods}

\section{Shellfish sampling site}

Samples of Mytilus galloprovincialis were collected in Olbia and Oristano's gulf, respectively in the northeast and west coast of Sardinia, in the shellfish farms and in purification center; while samples of Crassostrea gigas were collected from the breeding pond of San Teodoro (Figure 1; Table 1).

\section{Collection of samples and processing}

From April 2011 to February 2012, a total of 1335 specimens of mollusks (1095 Mytilus galloprovincialis and 240 Crassostrea gigas) were collected. The samples were identified and kept at $0-5^{\circ} \mathrm{C}$ until they reached the laboratory, where they were weighed (live weight) and pooled ( 6 pools of $15 \pm 2$ mussels/month and 5 pools of $4 \pm 1$ oysters/month). For each pool, gills with labial palps, and digestive gland (hepatopancreas) were collected from each subject. The pooled tissues were homogenised
Correspondence: Tiziana Tedde, Istituto Zooprofilattico della Sardegna, via Duca degli Abruzzi 8, 07100 Sassari, Italy.

Tel. +39.079.2892352 - Fax: +39.079.2892324.

E-mail: tizianatedde@gmail.com

Key words: Cryptosporidium sp., Giardia sp. Bivalve, Staining, PCR.

Acknowledgements: the authors are thankful to Salvatore Serra and Antonio Mura from the Local Healthcare Facility in Olbia, Luigi Giugliano from the Local Healthcare Facility in Oristano, and to Alessandro Mudadu from the Istituto Zooprofilattico Sperimentale della Sardegna.

Conflict of interests: the authors declare no potential conflict of interests.

Funding: the work was financially supported by the Italian Ministry of Health.

Conference presentation: the paper was presented at the 22nd AIVI National Conference, 2012 Sept. 19-21,Torino, Italy.

Received for publication: 19 March 2013.

Revision received: 24 April 2013

Accepted for publication: 24 April 2013.

This work is licensed under a Creative Commons Attribution 3.0 License (by-nc 3.0).

CC Copyright T. Tedde et al., 2013

Licensee PAGEPress, Italy

Italian Journal of Food Safety 2013; 2:e26

doi:10.4081/ijfs.2013.e26

in phosphate-buffered saline (PBS) $0.04 \mathrm{M}$ (pH 7.2-7.4), and the lipids were extracted by addition of diethyl ether. Then, the tube was vigorously hand shaked for $30 \mathrm{sec}$ and centrifuged at $1250 \mathrm{x} \mathrm{g}$ for $10 \mathrm{~min}$; the pellet obtained was placed in a $1.5 \mathrm{~mL}$ tube.

The light microscopy, immunofluorescence (IF) and polymerase chain reaction (PCR) methods were evaluated using spiked tissues, collected from 20 specimens of Mytilus galloprovincialis. For the tissue spiking experiments, from each mussel the digestive gland and gills were excised and inoculated with a 1 $\mathrm{mL}$ (00)cysts suspension obtained from calves and cats feces naturally infected.

Calf and cat feces were sived through a series of mesh strainers and then purified and concentrate using the method previously described for the mollusks pools.

\section{Oocyst detection and identification}

The pellet of each pool was divided in two aliquots: from the first aliquot, one drop of the pellet was streaked onto a glass slide and stained with modified Ziehl-Neelsen (Angus, 1987) and Auramine 0 for Cryptosporidium, and Chlorazol Black and Lugol's iodine (for 
Giardia). The slides were observed at light microscopy for modified Ziehl-Neelsen, Chlorazol Black and Lugol's iodine, and fluorescence microscopy for Auramine 0.

A direct IF antibody test was used to detect Cryptosporidium and Giardia (00)cysts in the pellet of first aliquot. Each pellet was pipetted onto slides. The slides were then processed according to the manufacturer's instructions (Merifluor ${ }^{\circledR}$ test Cryptosporidium/Giardia; Meridian Bioscience Inc., Cincinnati, OH, USA).

\section{Molecular procedures}

The second aliquot of the pellet was subjected to molecular tests. The pellet was resuspended in a lysis buffer $(120 \mathrm{mM} \mathrm{NaCl}, 10 \mathrm{mM}$ EDTA, 25 mM Tris-HCl, 1\% Sarcosyl, pH 8.0), according to the protocol Morgan et al. (1997), and subjected to three freeze/thaw cycles (liquid nitrogen $3 \mathrm{~min}, 37^{\circ} \mathrm{C} 3 \mathrm{~min}$ ), then incubated with proteinase $\mathrm{K}$ and DNA extracted with phenol-chloroform-isoamyl alcohol. DNA was stored at $-20^{\circ} \mathrm{C}$ until used for PCR analysis. Cryptosporidium genus-specific primers were used to amplify a fragment of about $300 \mathrm{bp}$ of the 18S rDNA variable region (Morgan et al., 1997). The PCR reactions contained $1 \mathrm{X}$ reaction buffer, $3 \mathrm{mM} \mathrm{MgCl}_{2}, 0.625 \mathrm{mM}$ dNTP, 25 $\mathrm{pmol} / \mathrm{\mu L}$ of each primer, $1 \mathrm{U}$ of Taq Gold (RocheBoehringer, Mannheim, Germany) and $1 \mu \mathrm{L}$ DNA in a $25 \mu \mathrm{L}$ total reaction volume.

Polymerase chain reactions were performed under the following conditions: $5 \mathrm{~min}$ at $96^{\circ} \mathrm{C}$, 30 cycles of $40 \mathrm{~s}$ at $94^{\circ} \mathrm{C}, 40 \mathrm{~s}$ at $60^{\circ} \mathrm{C}, 40 \mathrm{~s}$ at $72^{\circ} \mathrm{C}$, with a final 10 min elongation step at $72^{\circ} \mathrm{C}$. The Giardia PCR protocol was designed to amplify a 432 bp segment of the glutamate dehydrogenase $(G D H)$ gene from multiple genotypes of Giardia duodenalis with the degenerated primers described by Miller $e t$ al. (2005). Polymerase chain reactions contained $1 \mathrm{X}$ reaction buffer, $1.5 \mathrm{mM} \mathrm{MgCl}_{2}, 200 \mu \mathrm{m}$ dNTPs, $12.5 \mathrm{pmol} / \mathrm{\mu L}$ of each primer, $0.5 \mathrm{U}$ Taq polymerase, and $2 \mu \mathrm{L}$ DNA in a $50 \mu \mathrm{L}$ total reaction volume. Amplification conditions started with one cycle for $3 \mathrm{~min}$ at $95^{\circ} \mathrm{C}, 2$ cycles of 2 min at $94^{\circ} \mathrm{C}, 1 \mathrm{~min}$ at $56^{\circ} \mathrm{C}, 2 \mathrm{~min}$ at $72^{\circ} \mathrm{C}$, followed by 55 cycles of $30 \mathrm{~s}$ at $94^{\circ} \mathrm{C}, 20 \mathrm{~s}$ at $56^{\circ} \mathrm{C}$ and $45 \mathrm{~s}$ at $72^{\circ} \mathrm{C}$, with a final extension of 7 min at $72^{\circ} \mathrm{C}$. Polymerase chain reaction products were separated by gel electrophoresis in
1\% agarose gel stained with $\mathrm{Sybr}^{\circledR}$ Safe DNA Gel Stain 1X TAE (Invitrogen, Carlsbad, CA, USA).

\section{Results}

The mussels tissues spiked using an (0o)cystic suspension were detected by light microscopy, IF and PCR methods. The different diagnostic techniques gave negative results for Cryptosporidium and Giardia in all pools for both shellfish species.

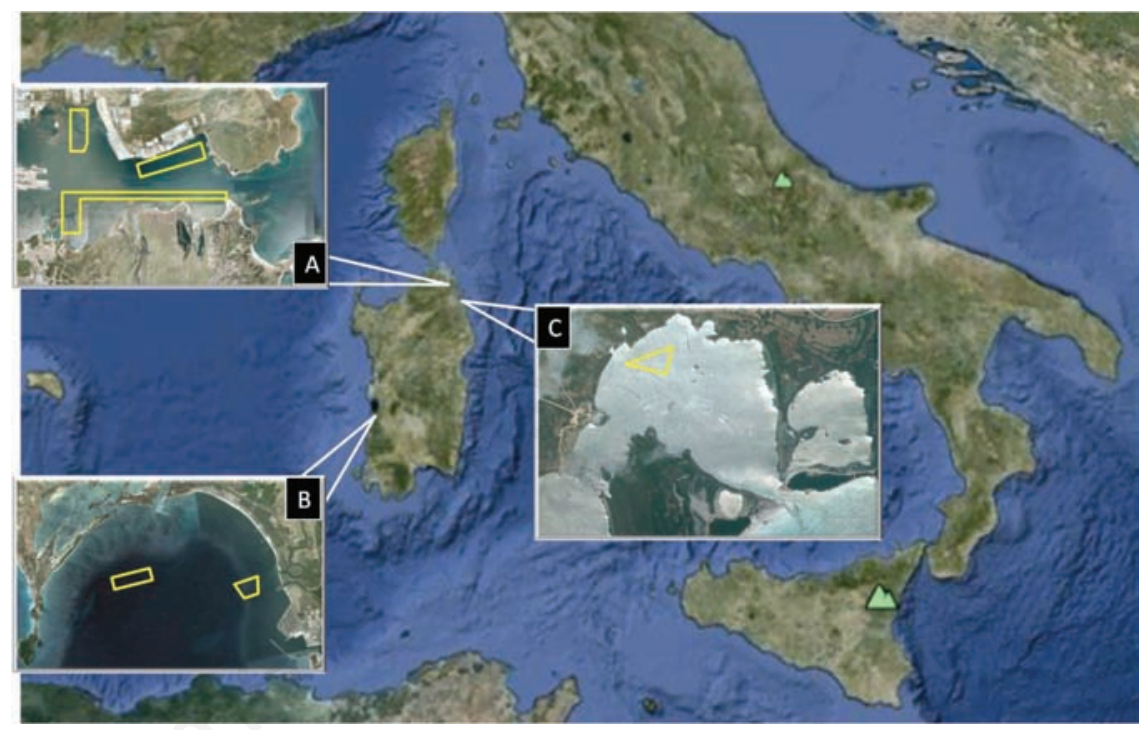

Figure 1. Maps of Sardinia region (Italy) and Oristano's gulf (A), Olbia's gulf (B), San Teodoro pond (C) with shellfish farms and collection site locations (in yellow).

Table 1. Mollusks species and relative sampling sites.

\begin{tabular}{|c|c|c|c|c|c|c|}
\hline Examined species & Localities & Sample (n) & Shellfish farms & Sampling site & \multicolumn{2}{|c|}{ Coordinates } \\
\hline \multirow[t]{13}{*}{ M. galloprovincialis } & Olbia & 675 & Cocciani cove & $\begin{array}{l}1 \\
2 \\
3\end{array}$ & $\begin{array}{l}40^{\circ} 55^{\prime} 50.05 ” \mathrm{~N} \\
40^{\circ} 55^{\prime} 47.57 ” \mathrm{~N} \\
40^{\circ} 55^{\prime} 36.18 ” \mathrm{~N}\end{array}$ & $\begin{array}{l}9^{\circ} 31^{\prime} 44.60 " \mathrm{E} \\
9^{\circ} 31^{\prime} 44.50^{\prime \prime} \mathrm{E} \\
9^{\circ} 31^{\prime} 48.89^{\prime \prime} \mathrm{E}\end{array}$ \\
\hline & & & Saccaia bay & 4 & $40^{\circ} 55^{\prime} 30.04^{\prime \prime} \mathrm{N}$ & $9^{\circ} 32 ’ 28.25 ” \mathrm{E}$ \\
\hline & & & & 5 & $40^{\circ} 55 ' 25.61 " \mathrm{~N}$ & $9^{\circ} 32^{\prime} 47.53$ ”E \\
\hline & & & & 6 & $40^{\circ} 55^{\prime} 25.79 ” \mathrm{~N}$ & $9^{\circ} 32$ ‘8.63"E \\
\hline & & & & 7 & $40^{\circ} 55 ' 29.22 ” \mathrm{~N}$ & 9॰33’22.92”E \\
\hline & & & Cavallo island & 8 & $40^{\circ} 55^{\prime} 09 ., 35^{\prime \prime} \mathrm{N}$ & $9^{\circ} 31^{\prime} 48,23 " \mathrm{E}$ \\
\hline & & & & 9 & $40^{\circ} 55^{\prime} 12.10^{\prime \prime} \mathrm{N}$ & $9^{\circ} 32^{\prime} 09,10^{\prime \prime} \mathrm{E}$ \\
\hline & & & & 10 & $40^{\circ} 55^{\prime} 14.10^{\prime \prime} \mathrm{N}$ & $9^{\circ} 32 ’ 31,60 ” \mathrm{E}$ \\
\hline & Oristano's gulf & 420 & Oristano's gulf & 1 & $39^{\circ} 52^{\prime} 53.19^{\prime \prime} \mathrm{E}$ & $8^{\circ} 28^{\prime} 25.18^{\prime \prime} \mathrm{N}$ \\
\hline & & & & 2 & $39^{\circ} 53^{\prime} 05.52^{\prime \prime} \mathrm{E}$ & $8^{\circ} 29^{\prime} 18.23 ” \mathrm{~N}$ \\
\hline & & & & 3 & $39^{\circ} 52^{\prime} 45.31^{\prime \prime} \mathrm{E}$ & $8^{\circ} 28^{\prime} 28.94 ” \mathrm{~N}$ \\
\hline & & & & 4 & $39^{\circ} 52^{\prime} 54.93^{\prime \prime} \mathrm{E}$ & $8^{\circ} 28^{\prime} 50.54^{\prime \prime} \mathrm{N}$ \\
\hline & & & & 5 & $39^{\circ} 52^{\prime} 58.15^{\prime \prime} \mathrm{E}$ & $8^{\circ} 29^{\prime} 20.88^{\prime \prime} \mathrm{N}$ \\
\hline C. gigas & S. Teodoro & 240 & S. Teodoro pond & $\begin{array}{l}1 \\
2\end{array}$ & $\begin{array}{l}9^{\circ} 40^{\prime} 23.80 " \mathrm{E} \\
9^{\circ} 40^{\prime} 27.80^{\prime \prime} \mathrm{E}\end{array}$ & $\begin{array}{l}40^{\circ} 48^{\prime} 43.30^{\prime \prime} \mathrm{N} \\
40^{\circ} 48^{\prime} 40.90^{\prime \prime} \mathrm{N}\end{array}$ \\
\hline
\end{tabular}

\footnotetext{
M. galloprovincialis, Mytilus galloprovincialis; C. gigas, Crassostrea gigas.
} 


\section{Discussion}

Oocysts of Cryptosporidium were recovered in clams (Chamelea gallina) collected in Italy at Vomano and Vibrata river mouths on the Adriatic sea (Molini et al., 2004; Traversa et al., 2004; Giangaspero et al., 2005). Other studies have shown the contamination of Mytilus galloprovincialis by Cryptosporidium oocysts in the lagoon Sacca di Scardovari (northern Adriatic sea), and in Messina area (Berrilli $e t$ al., 2008).

The results of this study represent the first data collected in Sardinia about Cryptosporidium and Giardia (00)cysts in specimens of Mytilus galloprovincialis and Crassostrea gigas. In the context studied here, though, unlike those mentioned above, light microscopy, IF and PCR assays showed that the shellfish were negative. Several factors may contribute to this: i) the concentration of (oo)cysts eventually present in breeding water is diluted because of several freshwater streams; ii) the water is often replaced and cleaned by the constant presence of circular currents and tides. Other factors such as chemical (i.e. ammonia, $\mathrm{pH}$ and salinity) and physical (i.e. temperature and solar radiation) parameters were reported to influence (oo)cyst concentration in the environment (Erickson e Ortega, 2006). Also, it should be noted that in summer - and more recently also in spring - the surface water temperature reaches $25^{\circ} \mathrm{C}$ in the studied area. Considering that shellfish are farmed in water between 50 $\mathrm{cm}$ and $2 \mathrm{~m}$ depth, direct sunlight may negatively influence the survival of protozoa (Giangaspero et al., 2009). In light of these results, we can reasonably consider the health risk of the farming areas comprised in this investigation to be low. Nevertheless, health risk cannot be considered absent in the areas which have not been examined.

Periodic monitoring is thus recommended, especially after the occurrence of the following conditions: a significant increase in the number of farms or animals in areas along the coastline; an increase in demographic pressure, in turn resulting in an increased wastewater disposal into the sea; and particularly intense and long-lasting rainfall, especially after prolonged periods of drought, in as much as this condition could make higher amounts of (00)cysts contained in manure residue accumulated in the soil go off into the sea.

\section{Conclusions}

In summary, as the source of potential con- tamination is provided by farms, the reduction of infection risk depends on the strategies for preventing and controlling the spread of intestinal parasites such as Cryptosporidium and Giardia in Sardinia livestock farms. The lack of such strategies would inevitably result in an increased risk of exposure to (00)cysts in various food, including edible bivalve mollusks.

\section{References}

Angus KW, 1987. Cryptosporidiosis in domestic animals and humans. In Practice 9:47-9.

Berrilli F, Caffara M, Capelli G, Fioravanti ML, Frangipane di Regalbono A, Giangaspero A, 2008. [Protozoi di interesse zoonosico in molluschi bivalvi: quale rischio per il consumatore? Note scientifiche pratiche]. [Book in Italian]. University of Bologna ed., Ozzano Emilia, Italy.

Erickson MC, Ortega YR, 2006. Inactivation of protozoan parasites in food, water, and environmental systems. J Food Protect 69: 2786-808.

Freire-Santos F, Oteiza-Lopez AM, VergaraCastiblanco CA, Ares-Mazás E, AlvarezSuárez E， García-Martín 0, 2000. Detection of Cryptosporidium oocysts in bivalve mollusks destined for human consumption. J Parasitol 86:853-4.

Giangaspero A, Cirillo R, Lacasella V, Lonigro A, Marangi M, Cavallo P, Berrilli F, Di Cave D, Brandonisio 0, 2009. Giardia and Cryptosporidium in inflowing water and harvested shellfish in a Lagoon in Southern Italy. Parasitol Int 58:12-7.

Giangaspero A, Molini, U, Iorio, Traversa D, Paoletti B, Giansante C, 2005. Detection of Cryptosporidium parvum (genotype 2) oocysts in seawater clams (Chamelea gallina). Prev Vet Med 63:209-12.

Giangaspero A, Molini U, Traversa D, Iorio R, Ceschia G, 2004. Giardia and Cryptosporidium in seawater clams (Chamelea gallina and Ruditapes philippinarum) of the Adriatic coast of central and northern Italy. Parassitologia 46(Suppl.1):153.

Glaberman S, Moore JE, Lowery CJ, Chalmers RM, Sulaiman I, Elwin K, Rooney PJ, Millar BC, Dooley JS, Lal AA, Xiao L, 2002. Three drinking-water-associated cryptosporidiosis outbreaks, Northern Ireland. Emerg Infect Dis 8:631-3.

Gomez-Couso H, Freire-Santos F, Amar CFL, Grant KA, Williamson K, Ares-Mazás ME, McLauchlin J, 2004. Detection of Cryptosporidium and Giardia in molluscan shellfish by multiplexed nested-PCR. Int J Food Microbiol 91:279-88.

Gomez-Couso H, Mendez-Hermida F, Castro-
Hermida JA, Ares-Mazas ME, 2005. Giardia in shellfish-farming areas: detection in mussels, river water and wastewaters. Vet Parasitol 13:13-8.

Graczyk TK, Fayer R, Cranfield MR, 1997. Zoonotic potential of cross-transmission of Cryptosporidium parvum: implications for waterborne cryptosporidiosis. Parasitol Today 13:349-51.

Graczyk TK, Thompson RCA, Fayer R, Adams P, Morgan UM, Lewis EJ, 1999. Giardia duodenalis cysts of genotype a recovered from clams in the Chesapeake Bay subestuary, Rhode River. Am J Trop Med Hyg 61:526-9.

Guiguet Leal DA, Pereira MA, Bueno Franco RM, Branco N, Neto RC, 2008. First report of Cryptosporidium spp. oocysts in oysters (Crassostrea rhizophorae) and cockles (Tivela mactroides) in Brazil. J Water Health 6:527-32.

Lowery CJ, Moore JE, Millar BC, McCorry KA, $\mathrm{Xu}$ J, Rooney PJ, Dooley JS, 2001. Occurrence and molecular genotyping of Cryptosporidium spp. in surface waters in Northen Ireland. J Appl Microbiol 91:774-9.

Miller WA, Atwill ER, Gardner IA, Miller MA Fritz HM, Hedrick RP, Melli AC, Barnes NM, Conrad PA, 2005. Clams (Corbicula fluminea) as bioindicators of fecal contamination with Cryptosporidium and Giardia spp. in freshwater ecosystems in California. Int J Parasitol 35:673-84.

Mladineo I, Trumbic Z, Jozic S, Segvic T, 2009. First report of Cryptosporidium sp. (Coccidia, Apicomplexa) oocysts in the black mussel (Mytilus galloprovincialis) reared in the Mali Ston Bay, Adriatic Sea. J Shellfish Res 28:541-6.

Molini U, Iorio R, Traversa D, Paoletti B, Giansante C, Giangaspero A, 2004. Rilievo di Giardia spp. e Cryptosporidium spp. nelle vongole (Chamelea gallina) della costa abruzzese. Ittiopatologia 1:34-40.

Morgan UM, Clare C, Constantine CC, Forbes DA, Thompson RC, 1997. Differentiation between human and animal isolates of Cryptosporidium parvum using rDNA sequencing and direct PCR analysis. J Parasitol 83:825-30.

Rodriguez-Hernandez J, Canut-Blasco A, Ledesma-Garcia M, Martin-Sanchez AM, 1994. Cryptosporidium oocysts in water for human consumption. Comparison of staining methods. Eur J Epidemiol 10:2158.

Traversa D, Giangaspero A, Molini U, Raffaella Iorio, Paoletti B, Otranto D, Giansante C, 2004. Genotyping of Cryptosporidium isolates from Chamelea gallina clams in Italy. Appl Environ Microb 70:4367-70. 